\title{
STABILITY OF STRUCTURAL GENE NUMBER IN DIPLOID SPECIES WITH DIFFERENT AMOUNTS OF NUCLEAR DNA AND DIFFERENT CHROMOSOME NUMBERS
}

\author{
M. L. ROOSE and L. D. GOTTLIEB \\ Department of Genetics, University af California, Davis, California 95616
}

Received 18.vii.77

\section{SUMmary}

The number of structural genes coding for a sample of electrophoretically detectable enzymes was determined for seven diploid species of Crepis which previously had been shown to vary in DNA/nucleus by seven-fold and to have chromosome numbers ranging from $2 \mathrm{~N}=6$ to $2 \mathrm{~N}=12$. The number of structural genes coding these enzymes was approximately 19 in all of the species examined, suggesting that gene number is conserved.

\section{INTRODUCTION}

IN the genus Crepis (Compositae, Cichorieae), DNA/nucleus of diploid species may vary as much as nine-fold (Jones and Brown, 1976). DNA amount is not correlated with chromosome number, which ranges from $2 \mathrm{~N}=6$ to $2 \mathrm{~N}=18$, although it appears to be correlated with chromosome volume (Jones and Brown, 1976). In general, total nuclear DNA amount varies by up to 65-fold among diploid species of higher plants (Sparrow et al., 1972; Flavell et al., 1974), including large differences among congeneric species (Rothfels et al., 1966; Chooi, 1971). While this raises a number of issues concerning the origin, evolution, and physiological effect of differences in DNA content, an important initial problem is to determine the present function of the DNA sequences added to or deleted from the genome.

One approach to this question has been determination of the proportion of the genome composed of repetitive and unique sequences in species differing in nuclear DNA content (Flavell et al., 1974). A second approach is to determine if differences in total amount of DNA are correlated with differences in number of structural genes. We present evidence that number of structural genes coding a random sample of enzymes detectable by electrophoresis does not change with DNA amount or chromosome number in seven diploid Crepis species. To our knowledge, this is the first comparison of gene number in closely related organisms which differ in these properties.

\section{MAterials AND METHODS}

Seeds were obtained from Dr R. N. Jones (Aberystwyth). See Jones and Brown (1976) for sources. Crepis mollis was from the Bremen Botanical Garden. The plants were grown in growth chambers until assayed. $0.3 \mathrm{~g}$ rosette leaf was ground in a mortar and pestle with $0.45 \mathrm{ml}$ of extraction buffer $\left(0 \cdot 10 \mathrm{M}\right.$ Tris- $\mathrm{HCl}, 10 \mathrm{~mm} \mathrm{KCl,} 1.0 \mathrm{~mm} \mathrm{MgCl}_{2}, 1.0 \mathrm{~mm}$ EDTA, $14 \mathrm{~mm}$ 2-mercaptoethanol, $0 \cdot 10 \mathrm{M}$ ascorbic acid, $p \mathrm{H} \mathrm{7.8)}$ and $0.1 \mathrm{~g}$ PVPP, spun for $6 \mathrm{~min}$. at $8000 \mathrm{~g}$ and the supernatent applied to wicks. Electrophoresis was conducted in 12.8 per cent starch gels using Tris-citrate gel buffer 
$(6.2 \mathrm{~g}$ Tris, $1.55 \mathrm{~g}$ citric acid monohydrate per litre) $p \mathrm{H} 8.30$ and lithium borate electrode buffer $(1.7 \mathrm{~g} \mathrm{LiOH}, 11.6 \mathrm{~g}$ boric acid per litre) $p \mathrm{H} 8.30$ according to standard techniques (Gottlieb, 1973b). 6PGD was resolved on 6 per cent acrylamide gels at $p$ H 9.5 (Gabriel, 1971). Standard staining methods were used (Gottlieb, 1973c; Brewer, 1970). At least two individuals per species were examined, except that only one $C$. grandiflora was available. AAT, aspartate aminotransferase; LAP, leucine aminopeptidase; PGI, phosphoglucoisomerase; GDH, glutamic dehydrogenase; $\mathrm{ME}$, malic enzyme; PGM, phosphoglucomutase; 6PGD, 6-phosphogluconate dehydrogenase; SOD, superoxide dismutase; CAT, catalase; MDH, malate dehydrogenase (NAD).

\section{RESULTS AND DISGUSSION}

We examined isozyme patterns of seven diploid species with chromosome numbers ranging from $2 \mathrm{~N}=6$ to $2 \mathrm{~N}=12$, and $\mathrm{DNA} /$ nucleus values ranging from 5.97 to $40.25 \mathrm{pg}$ (Jones and Brown, 1976). The electrophoretic patterns of the enzymes assayed were closely similar to those of the same enzymes in the related Stephanomeria (Compositae, Cichorieae) for which the mode of inheritance has been determined (Gottlieb, 1973a, 1977 and unpub.), making it possible to assign the number of coding genes in Crepis. General criteria for evaluating electrophoretic phenotypes were presented in Gottlieb (1973b).

The use of electrophoretic phenotypes to estimate the number of structural genes depends on the validity of several assumptions. Consider initially that increases in DNA amount result in duplication of structural genes. First, the duplicate gene must still code a similar enzyme which is active in the tissues examined and in our assay. This is primarily an assumption about the potential for divergence of the duplicate enzyme through time. Since we are dealing with a diverse group of enzymes, it is unlikely that all of the potential duplicate genes would now code enzymes with different catalytic properties, so that we expect to recognise at least some duplications if they had occurred. In addition, the species are in the same genus, indicating that their overall divergence has not been great and that they have a relatively recent common ancestor.

Second, the duplicate enzyme must have a different electrophoretic mobility than the ancestral one. Since the electrophoretic mobilities of more than half of the enzymes surveyed have diverged (table 1), we judge that if some of the coding genes had been duplicated, then at least some of their enzyme products would also have diverged in mobility and be recognised by our techniques.

Consider next that decreases in DNA amount, which actually is the general trend in Crepis from the ancestral perennial species to the more recent annual ones (Jones and Brown, 1976), mean loss or deletion of structural genes. In this case, the electrophoretic phenotype for some enzyme systems in some species, particularly those with smaller amounts of total DNA, would be comprised of fewer enzyme bands. We will assume that a reduction in the number of electrophoretic bands in a particular enzyme system in a species, relative to the number found in most other species, results from loss of the coding structural gene, and not that the particular individuals we assayed were homozygous for a null allele. 
TABLE 1

Somatic chromosome numbers, total DNA (Jones and Brown, 1976), isozyme mobilities ( $m m$ when front migrates $100 \mathrm{~mm}$ ), and estimated gene number in seven Crepis species*
C. zacintha C. capillaris
C. neglecta
C. rubra
C. mollis C grandiftora
C. siberica

Somatic chromosome

\begin{tabular}{|c|c|c|c|c|c|c|c|}
\hline number & 6 & 6 & 8 & 10 & 12 & 8 & 10 \\
\hline Total nuclear DNA (pg) & $5 \cdot 97$ & 13.07 & $16 \cdot 21$ & $15 \cdot 94$ & - & $36 \cdot 26$ & $40 \cdot 25$ \\
\hline \multicolumn{8}{|l|}{ Enzyme } \\
\hline \multirow[t]{4}{*}{ AAT 2.6.1.1 } & 17 & 18 & 09 & 24 & 19,28 & 23 & 23 \\
\hline & 34 & 40 & 35 & 35 & 34,40 & 43 & 43 \\
\hline & 48 & 48 & - & 51 & 48 & 51 & 48 \\
\hline & 24 & 一 & - & - & - & - & - \\
\hline \multirow[t]{3}{*}{ LAP 3.4 .1 .2} & 43 & 41 & 40 & 40 & 41 & 45 & 40 \\
\hline & 50 & 46 & 50 & 43 & 53 & 50 & 49 \\
\hline & 44 & - & - & 一 & 56 & 一 & - \\
\hline \multirow[t]{2}{*}{ PGI 5.3.1.9 } & 12 & -02 & 05 & 19 & 11 & 18 & 18 \\
\hline & 50 & 46 & 50 & 43 & 53 & 50 & 49 \\
\hline \multirow[t]{2}{*}{ GDH 1.4.1.2 } & 15 & 14,20 & 14 & 14 & 15 & 14 & 14 \\
\hline & 42 & 42 & 42 & 40 & 42 & 40 & 40 \\
\hline ME 1.1.1.40 & 26 & 28 & 26 & 25 & 26 & 26 & 27 \\
\hline \multirow{2}{*}{ PGM 2.7.5.1 } & 06 & 18 & 18 & 12 & 18 & 22 & 22 \\
\hline & 58 & 58,60 & 58 & 58 & 57 & 58 & - \\
\hline 6PGD 1.1.1.44 & 38 & 38 & 38 & 38 & 38,40 & 38 & 38 \\
\hline \multirow[t]{2}{*}{ SOD 1.15.1.1 } & 55 & 55 & 55 & 55 & 55 & 55 & 55 \\
\hline & 60 & 60 & 60 & 60 & 60 & 30 & - \\
\hline \multirow[t]{2}{*}{ CAT 1.11.1.6 } & 13 & 13 & 13 & 13 & 13 & 13 & 13 \\
\hline & 34 & 38 & 32 & 32 & 38 & 30 & 30 \\
\hline \multirow[t]{2}{*}{ MDH 1.1.1.37 } & 45 & 45 & 45 & 45 & 45 & 45 & 45 \\
\hline & 51 & 51 & 48 & 51 & 52 & 48 & 48 \\
\hline \multirow{2}{*}{$\begin{array}{l}\text { Estimated gene } \\
\text { number }\end{array}$} & & & & & & & 17 \\
\hline & 21 & 20 & 18 & 19 & 20 & 19 & 17 \\
\hline
\end{tabular}

* Each row represents a putative gene locus. Two mobilities entered in the same column indicate allozymes (enzyme variants coded by different alleles of the same locus).

Nearly all of the individuals assayed in the seven species had closely similar electrophoretic phenotypes for each of the 10 enzyme systems. Thus, the number of enzyme bands was nearly identical, and the relative mobilities of the enzymes within each system were similar across species. Only a few cases did not fit this general pattern: (1) homozygous and heterozygous individuals of $C$. mollis were observed for the genes coding AAT and 6PGD, and in C. capillaris, for those coding GDH and PGM (table 1); (2) all individuals sampled in $C$. zacintha had additional enzyme bands for AAT and LAP as did individuals of C. mollis for LAP (table 1). Since, with our small sample, we cannot tell if the additional bands reflect allelic heterozygosity or phenotypic (" fixed ") heterozygosity in which duplicated genes are each homozygous (Gottlieb, 1974), we treat them as if they represent the products of duplicated genes.

On the basis of the electrophoretic results, the seven Crepis species appear to have approximately 19 genes coding the sampled set of enzymes. Thus, their differences in total DNA and chromosome number are not correlated with differences in the number of genes specifying enzymes. If DNA that included structural gene sequences was gained, these sequences were rapidly silenced. If DNA was lost, it appears not to have included such sequences.

Other studies also suggest that the number of structural genes remains 40/1-L. 
relatively constant as DNA/nucleus varies. For example, analysis of DNA renaturation kinetics indicates that differences in repetitive DNA can account, in some cases, for variation in DNA content (Mikssche and Hotta, 1973; Wilson et al., 1976). The extensive study of Flavell et al. (1974) indicates that species with larger genomes $(>5 \mathrm{pg})$ have a larger proportion of repetitive sequences than species with smaller genomes $(<4 \mathrm{pg})$. However, among the former species, variation in DNA content from $6.9 \mathrm{pg}$ to $98 \mathrm{pg}$ did not correlate with the proportion of repetitive sequences, so that a substantial amount of the quantitative DNA variation could not be assigned to differences in repetitive sequences by this technique. The "complexity" (total length of different sequences) of polysomal mRNA isolated from cultured Drosophila and Aedes cells was found to be the same, even though these species differ five-fold in DNA content (Lengyal and Penman, 1975). Isozyme patterns of Amphiuma and human red blood cells had the same number of bands, in spite of the amphibian species having a 28-fold greater DNA amount (Comings and Berger, 1969). The general exception to constancy of structural gene number at the diploid level, is that variation does occur in number of rRNA genes (Maher and Fox, 1973; Mohan and Flavell, 1974). Only between diploid and polyploid species is there clear evidence for large changes in the number of genes coding for enzymes (Hart, 1973; Roose and Gottlieb, 1976). Whether the physiological significance of different DNA amounts is dependent on some genetic function of the altered sequences or is due to effects of DNA/nucleus on cell size and mitotic cycle time (Bennett, 1972) remains to be demonstrated. At any rate, structural gene number appears to be conserved at the diploid level.

Acknowledgments. We are grateful to Dr R. N. Jones for providing the Crepis seed used in this study.

\section{REFERENCES}

BENNETT, M. D. 1972. Nuclear DNA content and minimum generation time in herbaceous plants. Proc. R. Soc. London B, 181, 109-135.

BRewer, G. J. 1970. An Introduction to Isozyme Techniques. Academic Press, New York.

cHoor, w. y. 1971. Variation in nuclear DNA content in the genus Vicia. Genetics, 68, 195-211.

Comings, D. E., AND Berger, R. O. 1969. Gene products of Amphiuma: an amphibian with an excessive amount of DNA. Biochem. Genet., 2, 319-333.

FLAVELL, R. B., BENNETT, M. D., SMITH, J. B., AND SMITH, D. B. 1974. Genome size and the proportion of repeated nucleotide sequence DNA in plants. Biochem. Genet., 12, 257-269.

GABRIEL, o. 1971. Analytical disc gel electrophoresis. Meth. Enzymol., 22, 565-578.

GOTTLIEB, L. D. 1973a. Genetic control of glutamate oxaloacetate transaminase isozymes in the diploid plant Stephanomeria exigua and its allotetraploid derivative. Biochem. Genet., 9, $97-107$.

Gotrlieb, L. D. 1973b. Enzyme differentiation and phylogeny in Clarkia franciscana, C. rubicunda, and C. amonea. Evolution, 27, 205-214.

GorTliEB, L. D. 1973c. Genetic differentiation, sympatric speciation, and the origin of a diploid species of Stephanomeria. Amer. F. Botany, 60, 545-553.

GotTLIEB, L. D. 1974. Gene duplication and fixed heterozygosity for alcohol dehydrogenase in the diploid plant Clarkia franciscana. Proc. Nat. Acad. Sci. USA, 71, 1816-1818.

GOTTLIEB, L. D. 1977. Genotypic similarity of large and small individuals in a natural population of the annual plant Stephanomeria exigua ssp. coronaria (Compositae). F. Ecology, 65, 127-134.

HART, G. E. 1973. Homoeologous gene evolution in hexaploid wheat. Proc. 4th Intern. Wheat. Genet. Symp., 805-810. 
JONES, R. N., AND BROWN, L. M. 1976. Chromosome evolution and DNA variation in Crepis. Heredity, 36, 91-104.

LENGYAL, J., AND PENMAN, s. 1975. HnRNA size and processing as related to different DNA content in two Dipterans; Drosophila and Aedes. Cell, 5, 281-290.

MAHER, J., AND FOX, D. P. 1973. Multiplicity of ribosomal RNA genes in Vicia species with different nuclear DNA contents. Nature new Biol., 254, 170-172.

MIKSSCHE, J. P., AND HOTTA, X. 1973. DNA base composition and repetitious DNA in several conifers. Chromosoma, 41, 29-36.

MOHAN, J., AND FLAVELL, R. B. 1974. Ribosomal RNA cistron multiplicity and nuclear organizers in hexaploid wheat. Genetics, 76, 33-44.

ROOSE, M. L., AND GOTTLIEB, L. B. 1976. Genetic and biochemical consequences of polyploidy in Tragopogon. Evolution, 30, 818-830.

rothfels, K., sexsmith, E., heimburger, M., AND Krause, m. o. 1966. Chromosome size and DNA content in Ranunculaceae. Chromosoma, 20, 54-74.

SPARROW, A. H., PRICE, H. J., AND UNDERBRINK, A. G. 1972. A survey of DNA content per cell and per chromosome of procaryotic and eucaryotic organisms; some evolutionary considerations. Brookhaven Symp. Biol., 23, 45 I-494.

wilson, J. 'T., KATterman, F. R. H., AND ENDRizzi, J. E. 1976. Analysis of repetitive DNA in three species of Gossypium. Biochem. Genet., 14, 1071-1075. 